Revista de Estudios Histórico-Jurídicos

[Sección derecho romano]

XXXIX (Valparaíso, Chile, 2017)

[pp. $61-83$ ]

\title{
LA TRANSFORMACIÓN DE LA CIUDADANÍA ROMANA EN EL FIN DEL IMPERIO
}

[The transformation of the roman citizenshipat the end of the Empire]

\author{
Eduardo ANDRADES Rivas \\ Universidad del Desarrollo, Concepción, Chile*
}

\begin{abstract}
RESUMEN
El artículo trata de la ciudadanía romana en los tiempos finales del bajo Imperio Romano. Se estudian los efectos posteriores a la Constitutio Antoniniana y las vías en que la ciudadanía fue poco a poco degradándose hasta quedar despojada de contenido. Se analiza la oclusión de la misma, por la conversión del ciudadano en un verdadero súbdito y la mutación de la ciudadanía en virtud de la cual el ciudadano se transformó en cristiano católico. Finalmente se hace breve mención a la subsistencia del término durante los reinos bárbaros germánicos posteriores a Roma.
\end{abstract}

Palabras Clave

Ciudadanía romana - Constitutio Antoniniana - Bajo Imperio Romano Súbditos - Cristianos - Sidonio Apolinar - Teodosio I.

\section{Abstract}

This article deals with Roman citizenship in the late times of the lower Roman Empire. The effects after the Antonine Constitution and the ways in which the citizenship gradually became degraded until it was deprived of content, are analyzed. The occlusion of itself, by the conversion of the citizen into a real subject and the mutation of citizenship by virtue of which the citizen became a Catholic Christian. Finally, a brief mention of the subsistence of the term, during the baroque Germanic kingdoms after Rome, is done.

KEYWORDS

Roman citizenship - Constitutio Antoniana - Late Roman Empire-Subjects - Christians - Sidonius Apollinar Theodosius I.

ReCibido el 10 de abril y ACEPTADO el 30 de junio de 2017

* Profesor titular de Historia del Derecho y Cultura Occidental en la Facultad de Derecho e Instituto de Humanidades de la Universidad del Desarrollo. Dirección postal: Ainavillo 456, $5^{\circ}$ piso, Concepción, Chile. Correo electrónico: eandrade@udd.cl. 


\section{INTRODUCCIÓN}

Solo Roma puede exhibir una historia de ampliación, asimilación y emulación de su cultura, la famosa $\mathrm{r}$ o $\mathrm{m}$ a $\mathrm{n}$ i z a c i ó $\mathrm{n}$, tan exitosa en los pueblos que conquistó.

De ahí que tantos imperios luego de ella intentaron imitarla. Carlomagno y su intento frustrado por dar instituciones a las sociedades europeas que luego evolucionaron hacia el feudalismo; la monarquía hispánica y su Pax Austriaca; los turcos otomanos y su cultura de asimilación imperial; el Raj británico y, en nuestros días, los Estados Unidos de América.

Es el espíritu romanizador y uno de sus más importantes símbolos políticojurídicos, la ciudadanía romana ${ }^{1}$, lo que todos estos imperios posteriores buscaron emular, con suerte diversa pero sin nunca poder equiparse por completo con su modelo latino.

Por ello resulta tan importante poder determinar cómo y cuándo Roma perdió la capacidad de difundir su cultura y de qué manera la ciudadanía romana dejó de ser un atributo jurídico y cultural de primera importancia social para devenir en una carga de la cual se quería huir. Y lo que resulta igualmente importante, hacia donde huyeron los ciudadanos o ¿cuál fue su refugio?

A lo largo de este trabajo pretendemos estudiar lo que ocurrió en el orden jurídico y en la sociedad del Dominado y del Bajo Imperio para comprender debidamente el fenómeno descrito.

El punto de partida de este proceso de degradación y transformación de la ciudadanía romana está en la Constitutio Antoniniana de Civitate de $212^{2}$.

Pero sería injusto atribuirle toda la responsabilidad a la Constitutio de Caracalla sin considerar que la noción misma de ciudadanía había experimentado una evidente transformación (algunos hablan directamente de degradación) durante el Principado romano.

En efecto, recordemos que en sus orígenes la ciudadanía otorgaba a su titular ciertos derechos de muy diversa naturaleza y alcance.

Así, en tiempos de la República, los privilegios jurídicos que solo un ciudadano romano podía ejercitar eran ${ }^{3}$ :

Derechos de naturaleza política o de derecho público: i) el ius sufragii o derecho a participar como votante en las asambleas ciudadanas; ii) el ius honorum o derecho a ser candidato a las magistraturas electivas; iii) la provocatio ad populum o derecho

1 Con este trabajo finalizamos una investigación de larga data que comenzó con la publicación, en esta misma Revista de Estudios Histórico Jurídicos, de tres sucesivos estudios sobre la ciudadanía romana y su concesión como instrumento de romanización. Ver ANDRADES, Eduardo, La ciudadanía romana bajo los Julio-Claudios en REHJ., 29 (Valparaíso, 2007), pp. 165-208, ÉL MISMO, La ciudadanía romana bajo los Flavios y Antoninos en REHJ., 30 (Valparaíso, 2008), pp. 47-80 y ÉL MISMO, La ciudadanía romana bajo los Severos en REHJ., 31 (Valparaíso, 2009), pp. $87-123$.

2 A este notable documento dedicamos parte significativa de nuestro estudio La ciudadanía romana bajo los Severos. Ver ANDRADEs, Eduardo, cit. (n. 1), pp. 103-114.

3 Ver Tagle Martínez, Hugo, Ius sufragii y ius honorum, en Revista Chilena de Derecho, 20 (Santiago, 1993), pp. 345-352. 
de apelar a las condenas a muerte de un magistrado romana para ante los comicios centuriados, más tarde ante el emperador; iv) el derecho a integrar las legiones $y, v)$ ningún ciudadano romano podía ser sometido a tormentos en un juicio y la condena a muerte solo podía aplicarse en casos de crímenes de lesa majestad.

Derecho privado: i) el ius comercium o derecho de celebrar actos y contratos de acuerdo a la ley romana; ii) el ius connubium o el derecho de contraer matrimonio según el ius civile y adquirir la Patria Potestas sobre los miembros alieni iuris de su familia; iii) el ius testamentii o derecho de otorgar testamento y ser instituido heredero por otro ciudadano; iv) el ius actionis o derecho de ser parte en los procesos judiciales ante los magistrados de justicia romanos.

Los derechos políticos fueron abrogados hacia los inicios del Principado, cuando la masa de los ciudadanos de origen plebeyo en Roma aceptó tácitamente despojarse de los mismos a cambio de las prestaciones materiales que el fisco romano les otorgó, como el derecho a casa, alimentación y diversiones públicas, el panem et circensem que conocemos, y que fue establecido en tiempos de los JulioClaudios a fin de que el emperador contara siempre con el apoyo de dichas masas ${ }^{4}$.

Por su parte la exclusividad de los derechos privados fue poco a poco difuminándose cuando estos derechos comenzaron a ser concedidos progresivamente a nuevas categorías de personas que habitaban dentro del imperio a condición de que se tratase de sujetos libres. No es esta la oportunidad de reiterar este fenómeno que ya hemos descrito en otros estudios.

Sin embargo, lo que importa ahora es destacar como esta noción de ciudadanía romana ya universal, aunque degradada, mantuvo su vigencia en la mente de la población del imperio hasta mucho después de la Constitutio Antoniniana.

El propósito del presente estudio es analizar cuáles fueron las vías y formas por las que se fue transformando la ciudadanía, ocluyéndose en unos casos y mutando en otros.

Pues la condición de ciudadano se ocluye o desaparece cuando los pueblos germánicos forman los nuevos regna que reemplazan la autoridad imperial. Los dirigentes germanos consideran a la antigua población cristianorromana como sujeta a su poder, y por ello los antiguos ciudadanos devienen en súbditos. Aunque en rigor, este fenómeno de pérdida de derechos y de status ciudadano ya se había manifestado desde el Dominado en adelante. La misma autoridad romana del imperio tardío sería el modelo de régimen político para los reyes bárbaros que terminaron por reemplazarla. Y, paradigmáticamente, fue esta autoridad romana la que determinó cambiar desde el saludo ciudadano con la diestra en alto por

${ }^{4}$ La pesada fiscalidad que este tipo de beneficios impuso al erario romano no fue compensada ni por la política de trasladar población fuera de la capital imperial, mediante la fundación de colonias, ni por las sucesivas reformas tributarias que tendieron, hasta muy entrada la época imperial, a hacer recaer la carga fiscal sobre las provincias y no sobre Italia. Sobre la renuncia a los derechos políticos ciudadanos, nos dice el profesor Francisco. J. Andrés Santos: "La instauración del Principado clausuró definitivamente esa dimensión política de la ciudadanía romana, lo cual permitió a su vez su extensión por los emperadores a grupos cada vez más amplios de pobladores del Imperio". Ver ANDRÉS SANTOS, Francisco Javier, Ciudadanía romana y cosmopolitismo moderno, en Hispania Antiqua, 31 (Valladolid, 2007), p. 262 
la postración del súbdito hasta el conjunto de derechos que acompañaban a la ciudadanía romana como categoría jurídica y cultural. Es lo que estudiamos en la sección IV de este trabajo.

Y también decimos mutación pues, en efecto, es lo que ocurrió en las postrimerías del Imperio, cuando ya siendo éste cristiano, la ciudadanía fue poco a poco deviniendo en sinónima de la condición de cristiano, formando un binomio indisoluble. Así romani y catholicii fueron expresiones que se unieron hasta confundirse. En las secciones posteriores explicamos las causas de este fenómeno y las de otro vinculado al primero, el cómo la vía de entrada en la ciudadanía, en la sociedad civil se hizo a contar de dichos tiempos mediante la celebración de un sacramento religioso, el bautismo. Ello no puede dejar de constituir una ironía, pues en sus orígenes helenos y romanos la ciudadanía se reservaba, como bien recuerda Fustel de Coulanges, a quienes compartían el culto a los dioses de la ciudad, la religión del Estado o el culto oficial ${ }^{5}$. Nihil novum sub sole. Es lo que nos toca analizar desde la sección $\mathrm{V}$ en adelante.

Finalmente cabe destacar que la decadencia de la ciudadanía no fue un fenómeno aislado dentro de la civilización clásica. Por el contrario, fue parte del proceso de vulgarización de la cultura, del mismo derecho y del conjunto de la civilización dentro de lo que denominamos Antigüedad Tardía ${ }^{6}$.

\section{ESTADO DE LA CUESTIÓN}

El tema que nos ocupa tradicionalmente ha despertado poco interés en la historiografía jurídica, por lo que a las fuentes primarias de conocimiento hemos de agregar los estudios que nos proporciona la historiografía clásica ${ }^{7}$ especialmente la anglosajona, ${ }^{8}$ siempre tan preocupada de las cuestiones propias de la caída de la civilización antigua.

5 "Para dar la definición exacta del ciudadano hay que decir que es el que tiene la religión de la ciudad. Por el contrario, extranjero es el que no tiene acceso al culto y no goza de la protección de los dioses de la ciudad ni tiene derecho a invocarlos; porque los dioses nacionales no aceptan preces ni ofrendas más que de los ciudadanos y rechazan al extranjero, estándoles prohibida la entrada en sus templos y siendo un sacrilegio su presencia durante el sacrificio". Ver Fustel de Coulanges, Numa Dionisio, La ciudad antigua (traducción castellana de Alberto Fano, Madrid, Edaf, 1986), p. 181.

${ }^{6}$ Ver Grant, Michel, El mundo romano (1960, traducción castellana de Luis Gil, Madrid, Ediciones Guadarrama, 1960), pp. 91 ss.

7 Entre las obras que han tratado el tema en nuestro medio pueden citarse el ya clásico estudio de LevY, Ernst, The vulgarization of Roman Law in the Early Middle Ages en Mediaevalia et Humanistica, 1 (Boulder, 1943), pp. 14-40; Liebeschuetz, Wolf, Citizen Status and Law in the Roman Empire and the Visigothic Kingdom en PoHL, Walter y Reimitz, Helmut (eds.), Strategies of Distinction: The construction of Ethnic Communities, 300-800 (Leiden, Brill editors, 1998), pp. 131-152; ARCE, Javier, Bárbaros y romanos en Hispania (400-507 A.D.) (2005, primera reimpresión de la segunda edición, Madrid, Marcial Pons Historia, 2011); ARCE, Javier, Esperando a los árabes. Los visigodos en Hispania (507-711) (Madrid, Marcial Pons Historia, 2011), 344 pp. y Castellanos, Santiago, En el final de Roma (ca. 455-480) (Madrid, Marcial Pons Historia, 2013), 340 pp.

${ }^{8}$ Sobre el particular ver Mathisen, Ralph W., Peregrini, Barbari, and Cives Romani: 
No obstante, en los últimos años han sido publicados algunos estudios sobre el particular, que han contribuido a dar nuevas luces sobre el tema que nos ocupa.

Los trabajos surgidos en el tiempo reciente apuntan en dos líneas diferentes, pero complementarias. La primera revisa la vieja tesis sobre la crisis urbana del siglo III y cómo la emigración y fuga de los decuriones desde las urbes en decadencia ${ }^{9}$, a sus villas en el campo habría sido el antecedente más remoto de las formas feudales en las cuales dichas villas se habrían convertido en los dominios de un señor y los guardias de la villa en los bucelarios. Así la ciudadanía habría dado paso a las relaciones de señor y vasallo. Las más recientes aportaciones de la profesora Meiksins Wood apuntan, empero, en una dirección diversa, pues siendo el fenómeno recién descrito indesmentible en su origen, esto es, en la emigración al campo, no puede ser fehacientemente comprobado en cuanto a la transformación de las villas en dominios feudales. Antes bien, lo que aparentemente sucedió con las propiedades rurales de los potentados de las ciudades fue que poco a poco fueron abandonadas y ocupadas por gentes del mundo rústico. Y derruidas o saqueadas por las invasiones bárbaras del siglo V. Así, la feudalización tendría orígenes muy diversos a los de la huida al campo de las élites romanas.

La otra forma de entender el fenómeno es en el sentido de apreciar la transformación de la ciudadanía en una doble fase. Por una parte su conversión en sinónimo de fiel cristiano católico y paralelamente su degradación u oclusión final en la condición de súbdito. Las líneas conductoras de ambos procesos suelen mezclarse,

Concepts of Citizenship and the Legal Identity of Barbarian in the Later Roman Empire en The American Historical Review, 111 (Nueva York, 2006) 4, pp. 1011-1040. Asímismo GarnsEY, Peter, Roman Citizenship and Roman law in the Later Empire, en SwaIn, Simon y Edwards, Mark (eds.), Approaching Late Antiquity: The transformation from Early to Later Empire (Oxford, Oxford University Press, 2004), pp. 133-155. Con carácter general puede consultarse igualmente Grant, Michael, cit. (n. 6), pp. 91 ss., Meiksins WoOd, Ellen, De ciudadanos a señores feudales, historia social del pensamiento politico desde la Antigüedad a la Edad Media (1a edición, traducción castellana de Ferran Meler Ortí, Madrid, Paidós, 2011), 320 pp.; HeAtHer, Peter, La caída del Imperio Romano (2005, traducción castellana de Tomás Fernández Aúz y Beatriz Eguibar, Barcelona, 2a edición, Editorial Crítica, 2008), 712 pp.; FerrIL, Arther, La caída del Imperio Romano, las causas militares (1986, traducción castellana de Pilar González Bermejo, México, $3^{a}$ edición, Editorial Edaf, 1998), 304 pp.; RosEN, William, El fin del Imperio Romano, la primera gran peste de la era global (2007, traducción castellana de Marita Osés, Barcelona, Paidós, 2008), 416 pp.; y Jones, Terry y EREIRA, Alan, Roma y los bárbaros, una historia alternativa (2006, traducción castellana de Tomás Fernández Aúz y Beatriz Eguibar, Barcelona, Editorial Crítica, 2008), 464 pp.

9 Se ha puesto énfasis en la decadencia de la polis o ciudad desde el punto de vista del compromiso político y filosófico de sus dirigentes con la misma, así se sostiene que "Tanto el estoicismo como el epicureísmo pueden leerse como respuestas más o menos apolíticas a la decadencia de la polis o a la incertidumbre general y a la turbulencia de la época [...] La esfera de la acción y de la deliberación cívicas menguaron, enfocando al individuo privado en un extremo -sobre todo en el epicureísmo-y, en el otro, al orden universal de la c o s m ó p o l i s, en especial del modo en el que los estoicos lo concibieron. Si bien en el estoicismo hubo espacio, sobre todo en su forma romana posterior, para el deber cívico y el activismo político, estas dos escuelas helenísticas no situaron la felicidad humana en la polis, sino en los recursos internos del individuo". Ver MeIKSINS Wood, Ellen, cit. (n. 8), p. 141. 
de manera que no resulta muy sencillo separarlas y, tal vez, no sea conveniente hacerlo, pues se trató de fenómenos coetáneos y profundamente vinculados.

\section{La Ciudadanía romana tras la Constitutio ANTONINIANA}

Contrariamente a lo que se estima usualmente, la dictación de la Constitutio no significó la extinción de las categorías de personas excluidas de la ciudadanía romana en el Imperio. Es cierto que la universalización de la ciudadanía implicó la adopción del principio del derecho romano territorial, una misma ley vigente para todo el Imperio, pero no necesariamente importó la desaparición de estatutos jurídicos particulares, los que siguieron existiendo a lo largo de los últimos siglos de historia romana.

Pruebas históricas y jurídicas en abono de lo que decimos son la subsistencia del pretor peregrino en Roma y la dictación de constituciones imperiales que volvían a conceder la ciudadanía a grupos de gentes que habían quedado excluidas de la aplicación de la Constitutio $^{10}$.

Ahora bien, nos encontramos en la necesidad de precisar las razones por las cuales se produjo este fenómeno.

Al parecer, siguiendo lo que comentan Le Gall y Le Glay, lo que pudiera haber ocurrido es la subsistencia de los derechos locales dentro del amplio cobertor del derecho romano universal ${ }^{11}$. En nuestro medio ha sido el doctor Bancalari quien nos da noticia sobre las publicaciones que siguen esta corriente ${ }^{12}$. Por nuestra parte

${ }^{10}$ Desde luego subsiste la división historiográfica sobre la valoración de la Constitutio. Algunos la señalan como "una de las decisiones de mayor repercusión social del siglo III", como Mangas, Julio, Historia universal. Edad Antigua, Roma (Barcelona, Vicens Vives, 1999), pp. 387-388, no obstante que concede que la Constitutio significó "consagrar jurídicamente una situación de hecho por la que los nuevos ciudadanos mejoraban su estatuto jurídico sin necesidad de percibir mejoras en sus condiciones de vida. Con tal decisión, se conseguía una enorme simplificación de la administración a efectos de elaboración de los censos. Por su parte Charles Lawton Sherman la considera una de las mayores contribuciones de Roma a la civilización. Ver Lawton Sherman, Charles, The Constitutio Antoniniana in the Light of the Gnwmwn Tou Idiou Logou, en Transactions and Proceedings of the American Philological Association, 59 (Baltimore, 1928), p. 47. Otros, siguiendo a Dión Casio, siempre hostil al emperador, le atribuyen meros objetivos de recaudación impositiva, ver BENARIO, Herbert W., The Dediticii of the Constitutio Antoniniana, en Transactions and Proceedings of the American Philological Association, 85 (Baltimore, 1954), p. 188. Así, Rostovzeff y Bickermann, citados en la obra de Benario y el mismo Lawton Sherman al inicio de su ensayo, restan importancia a la dictación del edicto y lo reducen a una medida de fiscalidad. Ver Lawton Sherman, Charles, cit. (n. 10), p. 34 . En similares términos nos habla Piganiol, André, Historia de Roma (1939, traducción castellana de Ricardo Anaya, Buenos Aires, Eudeba, 1981), pp. 375 s.: "El derecho de ciudadanía romana pierde toda su valía, puesto que se concede a todos los habitantes del Imperio. Así desaparece la distinción, nacida de la conquista, entre romanos y súbditos. El imperio romano pierde el carácter de imperio colonial que había conservado hasta entonces". Y en el mismo sentido ver SHERwIN WhITE, Adrian Nicholas, The roman citizenship (2a edición, Oxford, The Clarendon Press, 2001), p. 445.

${ }^{11}$ Ver Le Gall, Joel - Le Glay, Marcel, El Imperio Romano (Madrid, Akal, 1995), p. 492.

12 Ver BanCalari, Alejandro, La Constitutio Antoniniana: aproximaciones significado y 
podemos citar una serie de fuentes jurídicas tardo clásicas y postclásicas que nos permiten probar esta afirmación. Así, en el Digesto de Justiniano, en pleno siglo VI, encontramos la siguiente referencia a los estatutos municipales de Campanos y Pónticos, con regímenes jurídicos diversos: "Qui ex duobus igitur campanis patentibus natus est, campanus est. sed si ex patre campano, matre puteolana, aeque municeps campanus est, nisi forte privilegio aliquo materna origo censeatur: tunc enim maternae originis erit municeps. ut puta iliensibus concessum est, ut qui matre iliensi est, sit eorum municeps. etiam delphis hoc idem tributum et conservatum est. celsus etiam refert ponticis ex beneficio pompeii magni competere, ut qui pontica matre natus esset, ponticus esset. quod beneficium ad volgo quaesitos solos pertinere quidam putant. quorum sententiam celsus non probat: neque enim debuisse caveri, ut volgo quaesitus matris condicionem sequeretur (quam enim aliam originem hic habet?): sed ad eos, qui ex diversarum civitatium parentibus orerentur ${ }^{13}$." En el mismo sentido encontramos disposiciones contenidas en el Código Theodosiano ${ }^{14}$.

¿Pero cuál era la razón de que la Constitutio hubiere agotado sus efectos tan pronto fue dictada? Una razón obvia es que el acto legislativo de Caracalla no haya sido concebido más que para producir dichos efectos en forma inmediata y no hacia el futuro. De seguir esta línea de pensamiento tendríamos que concluir forzosamente que toda persona que hubiese entrado en el Imperio con posterioridad al año 212 no se habría visto beneficiada con la adquisición de la ciudadanía romana. Pero poder concluir lo indicado es llevar demasiado lejos la interpretación del texto original de la Constitutio, cuya literalidad no nos permite asegurar, ni siquiera sugerir con algún grado de seguridad, que ese haya sido el propósito de Caracalla.

Por otra parte podríamos seguir otra posible interpretación, y ésta sería la de suponer, como lo hicieron los contemporáneos del hijo de Septimio Severo, que si el propósito de Caracalla era aumentar los ingresos del fisco romano con la concesión universal de la ciudadanía, entonces lo lógico habría sido que tal concesión hubiese tenido carácter permanente para de esta forma poder contar con nuevas fuentes de financiamiento en forma igualmente permanente.

Nos inclinamos por esta segunda tesis. Pero ello no nos permite responder a la existencia de grupos de personas, verificada ampliamente por la documentación histórica disponible, que siguieron excluidos de la ciudadanía romana tras la Constitutio. ¿Quiénes eran éstos habitantes del imperio pero no ciudadanos?

características, en Semanas de Estudios Romanos, 9 (Valparaíso, 1998), pp. 57-58.

${ }^{13}$ D. 50,1,1,2. Trad. española: "Así, pues, el que nació de dos padres Campanos, es Campano. Pero si de padre Campano y de madre Puteolana, es igualmente munícipe Campano, a no ser acaso que por algún privilegio se atienda al origen materno; porque entonces será municipe de donde es originaria la madre. Por ejemplo, se les concedió a los Troyanos, que el que es de madre troyana sea municipe de aquéllos. También a los de Delfos se les concedió y conservó esto mismo. También refiere Celso que a los Pónticos les compete por beneficio de Pompeyo Magno que sea Póntico el que hubieses nacido de madre Póntica. Cuyo beneficio opinan algunos que pertenece solamente a los habidos del vulgo; cuya opinión no aprueba Celso; pues no se debió disponer que el habido del vulgo siguiese la condición de la madre, porque ¿qué otro origen tiene éste? Sino a aquellos que nacieran de padres de diversas ciudades".

${ }^{14}$ Ver Mathisen, Ralph W., cit. (n. 8), p. 1017. 
Hay quien ha sostenido que se trataría de bárbaros recién ingresados en el Imperio. O sea, nuevos dediticios, producto de las campañas de conquista romanas. Pero tal afirmación no resiste la prueba histórica. Como sabemos, tras las campañas de los Antoninos, particularmente de Marco Aurelio no existen territorios que hayan sido técnicamente c o $\mathrm{n} \mathrm{qu}$ is $\mathrm{tad}$ o s, en el sentido de agregarlos junto a sus habitantes al Imperio. A lo más encontramos guerras que buscaban imponer nuevamente la ley romana a territorios que se rebelaron contra la autoridad imperial, como en el caso de Zenobia y su I m perio Palmirano en las provincias romanas orientales, en tiempos de Aureliano.

Por ello solo nos resta suponer que estos nuevos peregrinii deberían ser miembros de pueblos bárbaros que entraban en el imperio, en condiciones más o menos formales y que no investían la condición de ciudadanos pues ni siquiera hablaban latín. Pero esta explicación solo sería válida para los recién ingresados, ya que una vez asentados en el Imperio comenzarían a operar los mecanismos de asimilación y romanización que tan bien conocemos.

$\mathrm{Al}$ respecto recordemos que la relación que el Imperio tuvo con los pueblos de origen germánico no se caracterizó por ser un proceso ordenado y que a períodos de inestable convivencia seguían otros de enfrentamiento cada vez más sangrientos ${ }^{15}$. Fue la necesidad del propio Imperio, aquejado por la crisis demográfica a partir del siglo III, la que provocó la primera entrada de los germanos en territorios imperiales en calidad de mercenarios, colonos y foederat $i^{16}$.

Es cierto que en los días finales del Imperio algunos de los líderes bárbaros como Flavio Estilicón (359-408), de origen vándalo y Flavio Ricimero (405472), hijo de suevo y visigoda, obtuvieron las dignidades más altas dentro de las magistraturas romanas ${ }^{17}$, pero ello solo se explica porque estos líderes controlaban el poder militar organizado de los bárbaros y no porque naturalmente se les considerase romanos, pues nunca lo fueron ${ }^{18} \mathrm{ni}$ los decadentes líderes romanos los consideraron como parte de ellos.

En razón de lo que indicamos no resulta fácil postular una automática asimilación entre lo romano y lo ciudadano. Efectivamente, desde el punto de vista oficial constatado en las fuentes de la época, figuras como Menandro el rétor en sus Dos tratados de retórica epidíctica ${ }^{19}$, sostiene que es una sola la ley que gobierna en todo el Imperio ${ }^{20}$; y que todas las ciudades se rigen por leyes comunes ${ }^{21}$. Pero

15 A partir del 31 de diciembre de 406, cuando el límite natural del río Rhin se congeló permitiendo que los germanos y otros grupos como los alanos cruzaran a pie la vieja frontera.

16 Ver LeE, A. D., Information and Frontiers: Roman Foreign Relations in Late Antiquity (Cambridge, Cambridge University Press, 1993), 236 pp. Igualmente Harries, Jill, Imperial Rome AD 284 to 363: The New Empire (Edinburgh, Edinburgh University Press, 2012), 366 pp.

${ }_{17}$ Debe notarse que ambos adoptaron el prenomen de F $\mathrm{l}$ a v i o , en un intento de asimilarse a la romanidad. Ambos, también, fueron magister militum. El profesor Mathisen asocia la concesión de la ciudadanía romana a los bárbaros que desempeñaban funciones militares. Ver Mathisen, Ralph W., cit. (n. 8), p. 1022.

${ }_{18}$ De hecho Estilicón murió asesinado por orden del emperador Honorio.

19 Podemos fechar la obra en la segunda mitad del siglo III, entre el 272 y el 295.

${ }^{20}$ Ver: Menandro, el rétor, Dos tratados de retórica epidíctica, Tratado I, III, 360, 11-16.

${ }^{21}$ Ibíd., Tratado I, III, 363, 11-14 y III, 364, 14. 
enseguida se rectifica aceptando que todavía subsistían costumbres y usos propios de cada ciudad e incluso concede que podrían existir ciudades libres, o sea ciudades no romanas dentro del imperio, que mantuvieran su derecho original ${ }^{22}$.

Modestino, el jurista tardo clásico tan citado en el Digesto nos dice que "Roma communis nostra patria est" ${ }^{\prime 3}$, logro que se habría producido gracias a la dictación de la Constitutio ${ }^{24}$.

Pero desde el punto de vista historiográfico moderno la apreciación no necesariamente se mantiene. Mientras que Meiksins Wood coincide con las fuentes clásicas $^{25}$, otros historiadores disienten. En destacado primer lugar encontramos al profesor Tullio Spagnuolo quien sostiene que la variedad jurídica que existía antes de la Constitutio apenas si fue afectada por la misma ${ }^{26}$. Entre nosotros, el profesor Bancalari concluye algo parecido en su análisis sobre la vigencia del derecho romano en relación a los derechos locales ${ }^{27}$.

Si tomamos como principio del análisis el derecho positivo podemos llegar a una conclusión similar pues aunque luego de la Constitutio existe un ius commune imperial, perfectamente es dable pensar que pudo convivir con el ius propium de cada ciudad ${ }^{28}$. Un caso de particular interés al respecto es el del código egipcio del $I_{d i o l o g o s^{29}}$ que contenía las leyes aplicables a los egipcios nativos que no tenían la calidad de ciudadanos romanos y que rigió con posterioridad a la Constitutio Antoniniana.

Por su parte la epigrafía nos aporta varias pruebas para sustentar lo que sostenemos ${ }^{30}$.

Aunque ciertamente el tema diste de estar enteramente resuelto, todo parece orientarse en el sentido de aceptar que la Constitutio no significó la abrogación total e inmediata del derecho peregrino preexistente, sino que se produjo por largos

${ }^{22}$ Ibíd., Tratado I, III, 365, 13-14.

23 Roma es nuestra patria común. Ver Modestino, D. 50,1,33.

${ }^{24}$ En similares términos el contemporáneo de Caracalla, Gregorio Taumaturgo, en In Originem prosphonetica ac panegyrica oratio, reconoce la influencia de la Constitutio en la educación imperial. Ver VAN DAM, Raymond, Hagiography and History: the life of Gregory Thaumaturgus, en Classical Antiquity, 1 (Berkeley, 1982) 2, pp. 272-308.

25 Ver MeIKSins WoOd, Ellen, cit. (n. 8), p. 188.

${ }^{26}$ Ver Spagnuolo V., Tullio, Diritti locali e modello romano nel principato, en GonZÁLEZ F., Julián (ed.), Roma y las provincias, realidad administrativa e ideología imperial (Madrid, 1994), p. 224.

27 Ver Bancalari, Alejandro, Coexistencia o enfrentamiento entre el derecho romano y los derechos locales de las provincias, en REHJ., 26 (Valparaíso, 2004), pp. 25-39.

${ }_{28}$ Ver D’ORs, Álvaro, La formación del “ius novum” en la época tardo clásica, en REHJ., 4 (Valparaíso, 1979), pp. 35-49.

${ }^{29}$ Ver Lawton Sherman, Charles, cit. (n. 10), pp. 33-47, realiza un completo análisis y nos indica los principales cambios que significó la Constitutio para el sistema del Idiologos.

${ }^{30}$ Diversos ejemplos epigráficos confirman esta conclusión, como el caso de las lápidas de Afrodisia (Asia Menor), de 243 que señalan que el procónsul romano de la ciudad podría encontrarse frente a un derecho local aún vigente luego de más de 30 años de dictada la Constitutio Antoniniana. Ver Bancalari, Alejandro, Coexistencia o enfrentamiento, cit. (n. 27), p. 32. 
años una convivencia oficiosa sino oficial entre el derecho romano universal y los derechos indígenas locales ${ }^{31}$.

Finalmente detengámonos un momento en la última posibilidad. La de un ciudadano romano que perdiera la ciudadanía. Aparte de las fórmulas arcaicas ${ }^{32}$, a lo que apuntamos es a destacar la ciudadanía romana como un bien universal. Al término del Principado prácticamente todo hombre libre gozaba de ella y por lo tanto, quien no la poseía bien podía ser debido a sanciones penales como la deportatio in insulam ${ }^{33}$ o los trabajos forzosos en obras públicas de por vida. En tales casos el sujeto de las penas se volvía dediticio ${ }^{34}$.

\section{De ciudadanos a Súbditos, una oclusión de CIUDADANÍA}

Si las ideas anejas a la ciudadanía eran tan claras, tan universalmente compartidas por toda la población del Imperio, cabe preguntarse ¿̨cómo fue posible que la noción misma de aquella fuera extraviándose en el ethos colectivo hasta resultar propia de idealizaciones de un pasado añorado pero irrecuperable?

Se trata de un proceso lento pero perfectamente identificable desde sus inicios en el Dominado y aún antes. La adopción de formas políticas cada vez más influenciadas por los pueblos de Oriente, en particular de Persia, la transformación del Imperio en una monarquía más o menos absolutista con un corte militar semi permanente, todo ello contribuyó a que los ciudadanos fueran perdiendo la condición jurídica y cultural que caracterizó su estatus durante siglos ${ }^{35}$.

Cuando en tiempos de Diocleciano se terminó imponiendo la proskynesis $(\pi \rho 0 \sigma \kappa v ́ v \eta \sigma \iota \varsigma)^{36}$ ese proceso de pérdida de la ciudadanía estuvo casi completo. Más allá de conservar el vocablo de ciudadano, éste ya no significaba prácticamente nada ni para el común del pueblo ni para las autoridades, que recibían todo

31 Ibíd., p. 39.

32 Adecuadamente nos las recuerda GuZmán BRITO, Alejandro, Derecho privado romano (Santiago, Editorial Jurídica de Chile, 1996), I, pp. 330 s.

33 Exilio o confinamiento en una isla desierta.

${ }^{34}$ D. 48,19,2,1 y 48,19,17,1.

35 Sobre el particular ha destacado la profesora Ellen Meiksins Wood: "Los romanos, en verdad, inventaron una nueva concepción de la ciudadanía pasiva al conferir identidad de ciudadanos a los súbditos de su imperio, y el pueblo romano propiamente dicho ni siquiera ejerció jamás las funciones deliberativas que ejerció el demos en Atenas.” Ver MeIKSINS WoOD, Ellen, cit. (n. 8), p. 211. Por su parte el prof. Francisco J. Andrés Santos, sostiene en apoyo de lo que decimos, que "La ampliación e x t e n s i o n a 1 del concepto de ciudadano implicó la reducción i n t e n c i o n a l del mismo, haciéndose paulatinamente un tipo de ciudadanía menos d e n s a . A medida que aumentaba el número de sujetos titulares de la condición de ciudadano fue dándose una paulatina reducción de su esfera jurídica, hasta convertirse en un puro nomen iuris. En efecto, la civitas romana estaba asociada desde sus orígenes a un haz de derechos y deberes, entre los que destacaban los derechos de participación política y acceso a las instituciones [...]”. Ver AndrÉs SANTOS, Francisco Javier, cit. (n. 4), p. 261.

${ }^{36} \mathrm{El}$ estratego ateniense Conón se negó, entre otros coetáneos, a este acto humillante y repugnante para un griego, según refiere Marco Juniano Justino: Epítome de las "historias filípicas” de Pompeyo Trogo VI, 2, 12. 
su poder del cesarismo imperial y que se simbolizaba con el saludo de esclavos consistente en la postración del sujeto que debía tocar el suelo con su frente en señal de completa sumisión delante del emperador o de su genio o imagen. Esta ceremonia, impropia de tiempos en que el gobernante y gobernado se saludaban como iguales, ciudadanos, fue copiada prácticamente sin diferencias de la corte persa.

Ni siquiera la influencia cristiana pudo evitar este resultado. De hecho con posterioridad a los tiempos de Constantino, el ceremonial del Imperio seguía atribuyendo al emperador la categoría de semidivino.

Por último, en abono de lo que hemos afirmado, hay que recordar el otro factor que marcó el cambio de ciudadano a súbdito: la crisis urbana que se produjo en el Imperio, especialmente en su mitad occidental, por la cual las ciudades fueron perdiendo su población y sus élites gobernantes colapsaron bajo la pesada carga tributaria que debieron asumir sobre sus hombros por mandato de los gobiernos imperiales ${ }^{37}$. Ya lo dijo en su tiempo Pablo Orosio, al reconocer la decadencia de la urbe, lo que no cuestiona pese a su natural optimismo como romano cristiano, "similiter et Roma post annos totidem, hoc est MCLX et [fere] quattuor, a Gothis et Alaricho rege eorum, comite autem suo, inrupta et opibus spoliata non regno, manet adhuc et regnat incolumis" 38 . El fenómeno de la despoblación se hace ya irreversible a inicios del siglo $\mathrm{IV}^{39}$.

Cuando los últimos emperadores de Occidente determinan el cambio de la sede de la Corte desde Roma, ciudad empobrecida, a las ciudades fortalezas del norte, como Mediolanum, Aquilea o Rávena, también se hace evidente que quienes les acompañan no son ya los orgullosos ciudadanos romanos sino los súbditos de un nuevo y más precario dominio ${ }^{40}$.

Como sostiene Meiksins Wood, para fundamentar el dominio de la autoridad imperial cristiana en la antigüedad tardía, ya no bastaba con dividir a la comunidad entre los que estaban dentro y fuera de ella. Se necesitaba abolir la esfera cívica derivada de la antigua ciudadanía y reemplazarla por una comunidad cristiana

37 No es más que la confirmación de la clásica tesis de Mijail Rostovtzeff, según la cual la crisis del bajo Imperio realmente una crisis de la vida ciudadana. Ver RostovTzEFF, Mijail, Historia social y económica del Imperio Romano (traducción castellana de Luis López-Ballesteros, Espasa-Calpe S.A., Madrid, 1998), I, pp. 350 ss.

38 Traducción española: "Pues bien, de la misma forma, Roma, tras un número igual de años, es decir, mil ciento sesenta y casi cuatro más, ha sido atacada y privada de sus riquezas, aunque no de su imperio, por los godos y por Alarico, rey de aquéllos, y por el prefecto de la ciudad; a pesar de ello se mantiene todavía incólume”. Ver Orosio Paulo, Siete libros de historia contra los paganos, II, 3, 3. Esta traducción ha sido tomada de la edición de Editorial Gredos, (Madrid, 1982), p. 144.

39 Ver García Moreno, Luis A., La Antigüedad clásica, el Imperio Romano (Pamplona, Eunsa, 1989), II, pp. 448 s.

40 Sobre este paso de la vida cívica a la del dominio ver CECCONI, Giovanni Alberto, Governo imperiale e élites dirigenti nell'Italia tardoantica. Problemi di storia politico-amministrativa (270476 d.C.) (Como, 1994). Asímismo, concordamos con Andrés Santos: "La conversión de Roma en la C o s m ó p o 1 i s vislumbrada por los filósofos exigió, pues, el precio de la pérdida de la libertad política y la conversión del ciudadano en súbdito”. Ver ANDRÉs SANTOS, Francisco Javier, cit. (n. 4), p. 263. 
de seres humanos iguales en dignidad, pero afectados por el pecado, de lo cual derivaba que debían ser gobernados y no hacerlo por sí mismos ${ }^{41}$.

\section{LA ÚlTiMA TRANSFORMACIÓN: El CRISTIANISMO COMO AGENTE DE MUTACIÓN DE LA CIUDADANÍA}

El triunfo cristiano en el Imperio tuvo importantes consecuencias para el acceso y goce de la ciudadanía, aunque este es un aspecto que no suele ser recordado con frecuencia. En efecto, tras la dictación del Edicto de Milán por Constantino y Licinio en 313, las autoridades de la Iglesia, que pasaron a formar parte oficiosa y luego oficial del cursus honorum imperial, presionaron a fin de que la ciudadanía y los derechos que ella todavía comportaba a sus titulares, se reservara solo a los bautizados.

Con ello los paganos y bárbaros admitidos en el territorio del imperio iban siendo progresivamente desplazados de la ciudadanía y los primeros veían como se les despojaba de su condición ciudadana con múltiples expedientes. Herejes y judíos fueron igualmente privados del estatuto ciudadano y de la capacidad de valerse de los derechos que éste implicaba. Es decir, se les excluyó de la protección de la ley romana ${ }^{42}$.

El fenómeno se hizo irreversible desde el reinado de Teodosio en adelante ${ }^{43}$.

No deja de ser irónico como la historia de la ciudadanía experimentó un giro circular en torno a sus orígenes. Ello por cuanto, como bien indica Fustel de Coulanges en La ciudad antigua, la ciudadanía en sus inicios fue una consecuencia o emanación de la participación del individuo en el culto a los dioses de su ciudad ${ }^{44}$, por lo cual, quienes no participaban de dicho culto oficial no

41 "El dominio imperial, que exigía la obediencia a un soberano supremo, significaba que ya no bastaba simplemente con dividir el mundo social entre una comunidad política de ciudadanos y aquellos que estaban fuera de ella, como habían hecho Platón y Aristóteles. En cualquier caso, la igualdad de los seres humanos antes Dios era un principio esencial del cristianismo, de modo que el poder político podía justificarse, en términos cristianos, dividiendo la humanidad entre aquellos que pertenecían a una comunidad cívica y aquellos que estaban fuera y se hallaban subordinados a ella. En el marco de estas limitaciones, el modo más efectivo para justificar una autoridad imperial secular consistía en abolir por completo la esfera cívica. Incluso la variedad pasiva de ciudadanía imperial romana fue vaciada de cualquier sustancia que pudiera quedarle. Si los antiguos principios griegos de la comunidad política presuponían algún tipo de capacidad humana para el autogobierno -ya fuera innato a todos los hombres, tal como suponía Protágoras, o limitado a unos pocos, como en la teoría política de Platón-, esos principios cívicos podían cuestionarse mejor si se negaba semejante capacidad de alcanzar la virtud o el gobierno de sí. Y nada era más idóneamente adecuado a ese propósito que la doctrina agustiniana del pecado". Ver Meiksins Wood, Ellen, cit. (n. 8), p. 211.

${ }^{42}$ Ver Lo Nero, Carolina, Christiana dignitas: New Christian criteria for Citizenship in the Later Roman Empire en Medieval Encounters, 7 (Leiden, 2001) 2-3, pp. 146-164.

${ }^{43}$ Ver KInG, Noel Quinton, The Emperor Theodosius and the Establishment of Christianity (London, Westminster Press, 1961), 135 pp.

44 "Atenas y Roma acogían bien [...] y protegían al extranjero por razones de comercio y de política, pero ni su benevolencia ni su interés podían abolir las leyes antiguas establecidas por la religión, la cual no permitía al extranjero hacerse propietario, porque no podía poseer ninguna parte del suelo de la ciudad ni heredar del ciudadano, ni éste del extranjero, porque toda 
podían ser depositarios de la ciudadanía que se derivaba del mismo. Así pues, cuando los cristianos llegaron a la influencia política en el Imperio, aplicaron el mismo criterio con el que los antiguos atenienses o los romanos de la República temprana habían excluido de la ciudadanía a los extranjeros que no compartían el culto cívico oficial.

Así, podemos fijar el punto de inflexión en Teodosio el Grande ${ }^{45}$, quien sería el último gobernante de Roma en valorar la ciudadanía como un ideal político cultural vigente y no como algo del pasado ${ }^{46}$. Teniendo presente el panorama político del Imperio a fines del siglo IV tal proceder podría considerarse anacrónico, pero ello desconocería la valorización que las élites romanas aún tenían por su viejo ideario cívico. Siendo Teodosio de origen hispano ${ }^{47}$, esta cuestión resultaba particularmente importante para el sector social al que representaba ${ }^{48}$.

Pese a que el tiempo había transcurrido inexorable desde la época en que la ciudadanía era sinónimo de la condición jurídica y cultural propia de unos pocos dirigentes de origen latino, deviniendo aquella en universal y sinónimo de atributo de todo hombre libre, es de destacar que la idea de ciudadanía como fenómeno cultural sobreviviría con mucho a la ciudadanía desde el punto de vista jurídico. Y esa ciudadanía cultural universal sería la que se transmutaría en sinónimo de cristiandad $^{49}$.

Con su perspicacia habitual para formular juicios certeros sobre el período, Christopher Dawson lo señaló claramente ${ }^{50}$.

transmisión de bienes llevaba consigo la transmisión del culto, y era tan delictivo al ciudadano practicar el culto del extranjero como a éste el de aquél". Ver Fustel de Coulanges, Numa Dionisio, cit. (n. 5), p. 184.

${ }^{45}$ Algunos han concluido que cuando el cristianismo llega al poder tuvo lugar una casi inmediata persecución de los paganos. Ver EnjuTo S., Begoña, Julio Constancio, paladín de la aristocracia romana del siglo IV D.C., en Habis, 32 (Sevilla, 2001), pp. 495-503. Estimamos que esta tesis no pareciera ser correcta. De hecho Julio Constancio asumió la protección de las aristocracias no cristianas, pero fracasó debido, en gran medida, a que ya no existían grupos paganos que fueran significativos en el período.

${ }^{46}$ Es lo que Latinio Pacato Drepanio sostiene, para diferenciar a Teodosio de otros líderes que sólo consideraban a sus gobernados como súbditos, en su Panegírico del emperador: "Nuestro príncipe, en cambio, se ofrece a las miradas de todos y la gente puede ver tan a menudo a nuestro emperador como el día o el sol". Sobre el particular ver PARETI DE CANESA, María Eugenia, Teodosio ante la aristocracia pagana de Roma (Según el panegírico de Pacato), en Semanas de Estudios Romanos, 12 (Valparaíso 2004), pp. 213-232.

${ }^{47}$ Sobre el reinado de Teodosio consultar HuBENAK, Florencio, El hispano Teodosio y la cristianización del Imperio, en Hispania Sacra, 51 (Madrid, 1999) 103, pp. 5-42; y Lomas Salmonte, Francisco Javier, Teodosio, paradigma de príncipe cristiano: Consideraciones de Ambrosio, Rufino de Aquileya y Agustín sobre la imperial persona, en Studia Historica, Historia Antigua, 8 (1990), pp. 149-166.

${ }^{48}$ Ver Lomas Salmonte, Francisco Javier, cit. (n. 47), p. 153.

49 "La ciudadanía, por supuesto, ya no significaba lo que había significado en la polis democrática, sino que era un instrumento ideológico efectivo al servicio de la hegemonía imperial. Con el tiempo, esa ideología acabaría por transmutar la cosmópolis imperial romana, junto con la ley natural que la gobernaba, en la I g l e s i a u n i v e r s a 1 del cristianismo". Ver MeiKsins WoOD, Ellen, cit. (n. 8), p. 188.

50 “[...] Aun en la etapa más oscura del Imperio tardío, estas ideas nunca desaparecieron 
Cuando nos adentramos en el análisis de las mentalidades presentes en los romanos de la decadencia imperial, como Prudencio ${ }^{51}$ o San Agustín ${ }^{52}$, podemos apreciar que pese que hacía mucho tiempo se habían perdido las virtudes del amor a la patria, al trabajo duro y al esfuerzo personal, los intelectuales del periodo seguían rindiendo homenaje a ese conjunto de virtudes cívicas antiguas, que componían el corazón del ideario ciudadano de la Roma clásica. Ese mismo ideario se confundía con el del nuevo romano cristiano, pues las virtudes cívicas reconocidas antaño se transformaban en las virtudes cardinales del cristiano ${ }^{53}$. De hecho San Agustín sostiene que la "ciudad está en sus ciudadanos, no en sus murallas" 54 . El paso de la Roma terrenal, civitas terrestre a la Ciudad de Dios, civitas Dei, es particularmente significativo en la obra de San Agustín, para quien la Cristiandad es clara heredera cultural del Imperio Romano ${ }^{55}$.

Contamos con otros testimonios significativos sobre este proceso. Uno de ellos fue el galorromano Rutilio Namaciano, quien fuera político, senador y escritor en

completamente. Los romanos sentían que el Imperio estaba en todo lo que hubiera en el mundo de civilización, justicia y libertad, y hasta el siglo VII gustaban repetir el antiguo dicho de que entre los gobernantes de la tierra solamente el emperador romano reinaba sobre hombres libres, mientras que los jefes de los bárbaros dominaban esclavos”. DAwson, Christopher, Historia de la cultura cristiana (1950, traducción castellana, México, Fondo de Cultura Económica, 1997), pp. 91-93.

51 Aurelio Prudencio Clemente (348-410), pensador de la segunda mitad del siglo IV, sostiene que el factor que explica el sentimiento de $\mathrm{p}$ a $\mathrm{t} \mathrm{r}$ i a c o $\mathrm{m}$ ú $\mathrm{n}$ es el cristianismo, el imperio de Cristo y de ello se puede derivar que los romanos de su época vivan "como ciudadanos de una misma sociedad civil y como miembros de la misma casa”. Asimismo recordó que un romano podría contraer matrimonio con una mujer bárbara y su familia sería romana, ver Mathisen, Ralph W., cit. (n. 8), p. 1032.

52 Aurelius Augustinus (354-430), natural de Tagaste, Numidia, provincia de África, fue el gran intelectual del mundo romano tardío. Doctor de la Iglesia occidental fue el autor de numerosísimas obras sobre los más variados temas. El libro que nos interesa al efecto de sus observaciones sobre Roma y la ciudadanía o cristiandad es De civitate Dei o La ciudad de Dios. E igualmente una pequeña homilía titulada De Urbis excidio o De la devastación de Roma. Ver texto en español disponible en el sitio electrónico San Agustín, Augustinus Hipponensis: http:// www.augustinus.it/spagnolo/rovina roma/index2.htm (23-03-2017).

53 San Agustín, De Urbis excidio, II.2. Debe aclararse que San Agustín veía con preocupación la decadencia del Imperio y como se cuestionaba la obediencia a la autoridad secular. Ver Meiksins WoOd, Ellen, cit. (n. 8), pp. $211 \mathrm{~s}$.

${ }^{54}$ San Agustín, De Urbis excidio, VI, 6. Sobre el particular ver ChÁvez Aguilar, Pamela, De urbis excidio de San Agustín: razón y revelación en la comprensión de un acontecimiento histórico, en Teología y Vida, 52 (Santiago, 2011), pp. 245-252.

55 Ver Sherwin White, Adrian Nicholas, cit. (n. 10), pp. 461 s. y Lomas Salmonte: "Se trata, en definitiva, de la virtus romana de la que habla con calor y con cariño, hacienda gala de una Romanitas que se hace sentir igualmente en otros lugares de sus obras, mostrándonos una $\mathrm{r}$ o $\mathrm{m}$ a $\mathrm{n}$ a $\mathrm{v}$ i s i ó $\mathrm{n}$ de las virtudes, que tiene tanto más valor cuanto que procede de Agustín, un cristiano convencido que no deja, por ello, de sentirse orgulloso de ser romano. Ver Lomas Salmonte, Francisco Javier, cit. (n. 47), p. 161. Y en similar sentido, Pellizzari, Andrea, Roma communis nostra patria est. Costanti e variabili del patriottismo romano nei secoli dell'impero, en Atti della Accademia delle Scienze di Torino. Classe di Scienze Morali, Storiche e Filologiche, 133-134 (Turín, 2000), pp. 3-42. 
el siglo IV. En su caso la crítica al cristianismo se presenta en toda su obra ${ }^{56}$, de la que conservamos solo una mínima parte. A lo largo de su carrera como prefecto imperial de Toscana, Umbría y finalmente Roma entre 413 y 414, mantuvo una permanente admiración por las viejas virtudes cívicas romanas. Así afirma "Fecisti patriam diversis gentibus unam: profuit iniustis te dominante capi. Dumque offers victis proprii consortia iuris, urbem fecisti quod prius orbis erat" ${ }^{\prime \prime}$.

Esa es la constante de su creación literaria, el rescate de las viejas tradiciones romanas ya casi olvidadas y su comparación con el cristianismo, al cual critica. Aunque de hecho la comparación resulta sumamente similar particularmente en relación a las virtudes cardinales cristianas de la prudencia y fortaleza, "ordo renascendi est crescere posse malis" ${ }^{58}$. Es el ideal de la Roma que derrota a sus enemigos gracias a la fortaleza que le da ser una sociedad de hombres libres.

Otro ejemplo de lo que decimos es el del poeta romano de origen alejandrino, Claudio Claudiano. Viajó a Roma en donde permaneció entre 395 y 404, como miembro de la corte de Honorio. En su discurso en homenaje al general Estilicón sostiene respecto de Roma: "haec est in gremium victos quae sola recepit humanumque genus communi nomine fovit matris, non dominae ritu, civesque vocavit quos domuit nexu pio longinqua revinxit" ${ }^{2}$. Al igual que en el caso de Namaciano lo que Claudiano sostiene respecto de la civilización romana es anacrónico para su tiempo, pero no por ello deja de demostrar que los ideales ciudadanos se mantenían vigentes en la mente de los dirigentes del imperio aunque la propia ciudadanía se hubiere degradado hasta convertirse en una reliquia de tiempos remotos.

\section{Ciudadanía En el fin del Imperio, la Respuesta de} LAS ÉLITES

Finalmente, ya fuere por la vulgarización jurídica, ya por la decadencia general de la cultura, la ciudadanía va quedando relegada a la condición mínima que debían cumplir quienes se desempeñaban como magistrados en el cursus honorum

56 De reditu suo o El regreso, diario de viaje que narra su retorno desde Roma a Toscana. Se trata de un gran defensor de la historia de Roma, crítico del cristianismo y defensor de las antiguas creencias cívico-religiosas romanas. Para un estudio de las principales facetas del pensamiento de Namaciano Ver Ribagorda Serrano, Miguel, La pervivencia religiosa pagana en el siglo $V$ : el ejemplo de Rutilio Namaciano, en Antigüedad y Cristianismo, 14 (Murcia, 1997), pp. 179-187. Hay versión electrónica disponible en http://revistas.um.es/ayc/article/ view/65321/62941 (12-02-2017).

57 Rutilio Namaciano, De reditu suo, I, 63-66: Traducción española: "Para las naciones separadas unas de las otras has construido una sola patria; bajo el cautiverio de tu dominio que tuvo beneficios para todos, incluso para aquellos que no conocieron la justicia y que ofreciendo a los derrotados una parte de tu propia justicia, has cimentado una ciudad de lo que antes fue un mundo".

${ }^{58}$ Rutilio Namaciano, De reditu suo, I, 140: Traducción española: "El poder de crecer en las desgracias es la ley de la supervivencia”.

59 Claudio Claudiano, De Consulatu Stilichonis, III, 24, 151-154: Traducción española: "Ella sola es la que ha recibido a los conquistados en su seno y ha nutrido al género humano bajo un mismo nombre, no como una emperatriz sino como una madre para compartir su ciudadanía y uniendo pueblos lejanos con vínculos de afecto”. 
imperial. Estas funciones terminaron por ser sinónimas de ciudadanía, pues solo un ciudadano podía desempeñarlas ${ }^{60}$. Sin embargo a partir de inicios del siglo $\mathrm{V}$, con la entrada masiva e incontenible de los bárbaros germanos en territorio imperial, todo el sistema burocrático romano fue dislocado, dejando como resultado que las magistraturas fueron desapareciendo aceleradamente ${ }^{61}$.

Las familias más notables de las provincias debieron entonces buscar nuevas fuentes de seguridad para ellas mismas y sus allegados, a medida que el orden imperial se batía en inevitable retirada ${ }^{62}$.

Fue así como encontraron en la jerarquía de la Iglesia una nueva vía de influir en la sociedad en constante cambio. La Iglesia, cuerpo social vivo y en expansión, de la misma forma en que el agonizante Imperio había hecho antes, acogió a los antiguos decuriones, senadores y magistrados quienes accedieron a las dignidades episcopales y sacerdotales, casi sin solución de continuidad. El fenómeno es perfectamente identificable en Hispania y en las Galias ${ }^{63}$.

Dos ejemplos arquetípicos de tal actitud fueron Hidacio, Obispo de Chaves ${ }^{64}$ (400- c. 469) en Gallaecia y San Sidonio Apolinar, Obispo de Clermont Ferrand ${ }^{65}$ (431-489) en las Galias.

En el caso del obispo de Chaves, su Chronicon o Chronica tenía por objetivo

${ }^{60}$ Es interesante observar cómo estas funciones y dignidades se fueron volviendo símbolos de ciudadanía, de la misma forma en que el modo de vida, las ropas y la lengua latina. Ver Castellanos, Santiago, cit. (n. 7), p. 217.

61 "La estructura jerárquica adoptada por la Iglesia católica no predisponía a que la ciudadanía pudiera arraigar con cierta fuerza. La caída del Imperio provocó que los obispos asumieran no sólo el poder espiritual sino también el político en cada diócesis." Ver Horrach Miralies, Juan Antonio, Sobre el concepto de ciudadanía: historia y modelos, en Factótum, 6 (Salamanca, 2009), p. 9.

62 "Desde hacía tiempo los obispados solían ser destinos pretendidos por miembros de la poderosa aristocracia romana, en cualquiera de sus rangos". Ver Castellanos, Santiago, cit. (n. 7), p. 230.

63 "Se percibe que las aristocracias romanas de la Galia no solo apostaron por introducir cuadros ya definitivamente en el clero y en concreto en los obispados, sino que operó un esfuerzo intelectual de redefinición del sentimiento de pertenencia al mundo romano". Ibíd., p. 241.

${ }^{64}$ Hidacio, fue miembro de una importante familia hispanorromana de la aristocracia de Gallaecia. Su padre tenía grandes propiedades en Hispania y por ello Hidacio gozó de una educación excepcional. Pero en vez de ingresar al cursus honorum se dedicó a viajar por las provincias orientales del Imperio, llegando a conocer a San Jerónimo y a su retorno se dedicó a la carrera eclesiástica, siendo consagrado obispo de la diócesis de Aquae Flaviae, hoy Chaves, en 427. Fue en dicha dignidad en donde enfrentó a los suevos, a quienes retrató negativamente en su famosa Crónica. Ver ARCE, Javier, Bárbaros y romanos, cit. (n. 7). El texto de la Crónica consultado se encuentra disponible en la Biblioteca Latina digital, Ver Idatius Aquaeflaviensis Episcopus - Chronicum versión latina disponible en http://www. thelatinlibrary.com/hydatiuschronicon.html (consultada en 08-01-2017) Existe edición bilingüe latina española digitalizada del Episcopologio Asturicense disponible en la Biblioteca Digital de Castilla y León: http://bibliotecadigital.jcyl.es/i18n/catalogo imagenes/grupo. cmd? interno $=S \&$ path $=1006419 \&$ presentacion $=$ pagina\&posicion $=1$ \&registrardownload $=0$ (11-01-2017).

${ }^{65}$ Gayo Solio Apolinar Sidonio, o San Sidonio Apolinar (431-489) fue uno de los últimos patricios romanos, originario de las Galias. Es una de esas personalidades que marcan profundamente a la época en que les toca vivir. Militar, orador, político, intelectual, jurista y 
inicial el constituir una historia general del Imperio en su tiempo, aunque en la práctica Hidacio terminó centrándose en los sucesos de su lugar de origen y a las invasiones Suevas y Visigodas. En su carácter de romano desempeñó frecuentemente misiones diplomáticas. Con respecto al tema que nos ocupa su obra está llena de referencias negativas contra los bárbaros, especialmente los suevos, a los que cataloga como criminales y destructores de la civilización. Es en este punto en donde usa frecuentemente las voces de romano y cristiano como sinónimos. El ataque de los suevos a la forma de vida romana era, para él, un ataque a la cristiandad $^{66}$.

Sin embargo, mucho más impresionante es la carrera de su contemporáneo y también obispo, San Sidonio Apolinar.

Gayo Solio Apolinar Sidonio, o San Sidonio Apolinar (431-489) fue un romano con origen en las Galias cuya espectacular carrera nos permite apreciar el paso desde las magistraturas romanas a la jerarquía de la Iglesia. En otra oportunidad nos hemos referido con detalle a su perfil biográfico ${ }^{67}$.

Sidonio recibió una esmerada educación en oratoria y poesía clásica. Pasó de desempeñar activamente las magistraturas en su Galia de origen a las de la propia capital imperial. Yerno del emperador Avito, compuso su panegírico, que pronunció ante el Senado ${ }^{68}$ y luego los de 2 emperadores posteriores ${ }^{69}$.

finalmente activo obispo cristiano. Nacido en Lugdunum (Lyon), Galia, fue miembro de una de las más influyentes, ricas y principales familias de la aristocracia galorromana de su tiempo.

${ }^{66}$ Ver Hidatius, Chronicon, XVII y siguientes.

${ }^{67}$ Su obra completa se encuentra recogida en los Monumenta Germaniae Historica, Auctores Antiquissimi, vol. VIII. En versión latina y francesa existe la de Gregorre, J. F. y CollombeT F. L., Oeuvres de C. Sollius Apollinaris Sidonius, Traduites en Francais avec le Texte en Regard et des Notes (París, Broché, 1836) I y II. La biografía más famosa de Sidonio, en dos tomos, es la editada en el siglo XIX por el padre Chaix. Ver ChaIX DE LAVARÈnE, Louis Antoine C., Saint Sidoine Apollinaire et son siécle (Clermont-Ferrand, Ferdinand Thibaud Imprimeur Libraire, 1866), 913 pp. Hay versión digitalizada de esta biografía en el sitio electrónico https://archive. org/details/saintsidoineapo00lavagoog (23-03-2017). Asimismo destacamos la biografía del Rev. Padre Alban Butler, inserta en su Vidas de los Santos, ver Butler, Alban, Vidas de los Santos de Butler (1954, traducción castellana de Wilfredo Guinea, S. J., México, Orozco y Berra, 1965), III, pp. 384 s. En versión inglesa, una síntesis de su vida puede consultarse en STEVENS, C. E., Sidonius Apollinaris and his Age (Oxford, Clarendon Press, 1933), 224 pp. La edición completa de las cartas de San Sidonio se encuentra en lengua inglesa en DALTON, O. M. The letters of Sidonius (Oxford, The Clarendon Press, 1915), I-II. Hay versión digitalizada en el sitio web Tertulian.org, en http://www.tertullian.org/fathers/ \#sidonius apollinaris (22-02-2017). La versión íntegra y original en latín de sus obras, se encuentra en el sitio web The Latin Library, disponible en http://www.thelatinlibrary.com/sidonius.html (11-01-2017). Para múltiples materiales sobre Sidonio, véase el sitio web http://www.sidoniusapollinaris.nl (08-12-2016). Igualmente hemos escrito sobre su trayectoria político religiosa en ANDRADES RIVAS, Eduardo, El significado histórico-jurídico de las Leyes Teodoricianas, en REHJ., 38 (Valparaíso, 2016), pp. 47-75.

${ }_{68}$ Ver el texto original latino, de gran interés por la erudición y elocuencia del autor, en The Latin Library, disponible en el sitio http://www.thelatinlibrary.com/sidoniuscarmina.html (02-03-2017).

69 Mayoriano (420-457-461) y Antemio (420-467-472). En relación al panegírico de Mayoriano resalta la idea de Sidonio al exhortar al nuevo emperador a la reconquista del África en poder de los vándalos, apelando al deber del gobernante de amparar a los buenos cristianos y/o ciudadanos romanos, conceptos que utiliza frecuentemente y como sinónimos en el texto. 
Miembro por derecho propio del senado romano y prefecto de la Urbe bajo el reinado de Antemio. En lo que nos interesa, conviene recordar que Sidonio fue de aquellos líderes que entendió que el tiempo del Imperio había finalizado. Y por ello abandonó el cursus honorum imperial, por la carrera eclesiástica ${ }^{70}$. Así, aceptó ser preconizado Obispo de Arvenum (Clermont-Ferrand) siendo electo por aclamación popular y de los obispos de Auvernia. Alcanzaría los altares, según nos dice Butler ${ }^{71}$, más que por sus méritos eclesiásticos, por haber sido hasta el final de sus días un patriota que defendió a los romanos (cristianos católicos) de su diócesis contra los bárbaros (los godos arrianos de Eurico) ${ }^{72}$. Nuevamente podemos ver como el carácter de ciudadano y cristiano se confundía al punto de transformarse en sinónimos.

\section{LA CIUDADANÍA BAJO LOS GERMANOS}

Sin perjuicio de lo que ya hemos indicado, la noción cultural de ciudadanía romana fue ampliamente conocida y utilizada por los pueblos germanos que ocuparon las antiguas provincias imperiales ${ }^{73}$. En particular los visigodos asentados en las Galias y luego en Hispania usaron el concepto para diferenciar a sus súbditos de origen romano de los miembros de las sippes godas. Así las leyes de los reyes godos posteriores a Eurico establecieron numerosos ordenamientos jurídicos aplicables a "godos y romanos"74. Entendiendo que cuando los germanos se referían a

${ }^{70}$ Un completo análisis del tema del paso de San Sidonio del orden político romano al eclesiástico puede consultarse Castellanos, Santiago, cit. (n. 7), pp. 229 ss. y pp. 241 ss.

${ }^{71}$ Ver Butler, Alban, cit. (n. 67), pp. 384 s.

${ }^{72}$ En la hora undécima del Imperio Sidonio continuaba afirmando el valor de ser ciudadano. Así sostenía en un poema que dedicó a su amigo Consencio de Narbona: "seu nos Limpidii lares habebant, civis magnifici virique summi" "fuimos acogidos en la casa de Limpidio, magnifico ciudadano y gran hombre"). Ver San Sidonio Apolinar, Carmina y epistulae 23, en LoYen, André (ed.), Sidoine Apollinaire, Poémes (París, Les Belles Lettres, 1960), I, pp. 475-476.

73 "Barbarian kingdoms also preserved concepts of citizenship that sometimes, but not always, were related to legal jurisdiction. They gave particular attention to safeguarding the rights of those identified as Roman citizens. Both the Visigoths and the Burgundians preserved a law of Constantine dealing with slaves who were made 'Roman citizens, Regarding inheritances, the Visigothic interpretation of a law of Valentinian III referred to 'the succession rights of liberti who are Roman citizens, And the 'Burgundian Law of the Romans' included regulations dealing with witnessing procedures and the wills of Roman citizens. In late-sixth-century Italy and seventh-century Spain, slaves still were being formally manumitted and granted 'Roman citizenship'. And well into the ninth century, legal forms in the Frankish kingdom continued to convey 'Roman citizenship', which 'included the right to make a will, to give testimony, to buy, to sell, to endow, and to commute,' just as in the Roman period. Y 'The permeability of various forms of citizenship status in the barbarian kingdoms helps to explain why the transition from Roman to barbarian administrations just before and after the year 500 was not nearly as disruptive as it might have been. Roman administrative systems were preserved, as were institutions relating to personal legal status and procedures for all citizens of a kingdom. An additional consideration is that being identified as a Roman citizen was simply a statement of coverage under Roman ius civile. It did not carry any sense of political loyalty to the Byzantine emperor or the old Roman Empire'. Ver Mathisen, Ralph W., cit. (n. 8), pp. 1038 y 1039. En tal sentido consultar CTh. 4,7,1.

74 "La identidad romana había estado asociada durante siglos al vínculo con la dimensión 
r o m a n o hablaban de la población galo e hispanorromana católica que habitaba en abrumadora mayoría los territorios que ahora gobernaban ${ }^{75}$.

\section{CONCLUSIONES}

1. La dictación de la Constitutio Antoniniana de Caracalla transformó la ciudadanía, que se volvió universal, pero la Constitutio también contribuyó a una verdadera vulgarización de ésta.

2. Mientras que la ciudadanía se transformaba en un atributo de la inmensa mayoría de los habitantes del imperio, algunos de ellos permanecieron fuera del beneficio, especialmente los dediticios y los germanos recién ingresados en el Imperio junto a sus familias.

3. La Constitutio de Caracalla no abrogó la totalidad de los derechos locales existentes a lo largo de las provincias del Imperio. Fueron muchas las ciudades que conservaron sus usos y costumbres locales a la vez que el derecho romano que ahora regía en forma general.

4. Tras el término del principado se inicia un lento pero sostenido proceso de degradación cultural de la ciudadanía. Por una parte, se pierden los últimos derechos asociados a la misma y por otro la condición de ciudadano se rebaja hasta convertirse en la de súbdito a partir del Dominado.

5. Paralelamente, a medida que el cristianismo iba creciendo se produjo un proceso de mutación de la ciudadanía, en virtud del cual ésta devino en sinónimo de cristiano. Así, mientras el Imperio se bautizaba, sus habitantes se hacían cristianos y la entrada a la comunidad imperial se asimilaba a un sacramento, el del bautismo.

Aunque en el Bajo Imperio la ciudadanía ya no era más que un recuerdo vago en la mente de intelectuales nostálgicos, ella conservó su viejo prestigio entre las élites imperiales ${ }^{76}$.

política, con la res publica en cualquiera de sus formas, la republicana o la imperial. A partir de ahora la identidad romana debía ser sustentada en otro tipo de fundamentos, y la aristocracia exploró otros que, siendo tradicionales, iban a pasar a ser únicos. La cuestión era cómo negociar sus posiciones, que tenían que ver con la adecuación a las gentes y a los regna". Ver CaSTELLANOS, Santiago, cit. (n. 7), pp. 273-274.

${ }^{75}$ Una confirmación de lo que decimos y que se desarrolla para los vándalos, es la contenida en la crónica de Victor episcopus Vitensis o Víctor de Vita (c. 440-484), Historia de la persecución vándala, escrita a fines del siglo V. "La idea clave, más bien, es presentar la necesidad del mantenimiento de la identidad romana, que en Víctor es equivalente a la católica, romani y chatolici son una parte del binomio, la otra son los Vandali, que son Arriani". Ver Castellanos, Santiago, cit. (n. 7), p. 279. Un completo análisis de la obra de Víctor puede examinarse FourNIER, Eric, Victor of Vita and the Vandal "persecution": Interpreting Exile in Late Antiquity (Santa Bárbara, University of California, 2008), 320 pp. La edición de la obra original de Víctor que hemos tenido a la vista es la de John Moorhead, ver Víctor of Vita, History of the Vandal Persecution (traducción inglesa de John Moorhead, Liverpool, Liverpool University Press, 1992), $136 \mathrm{pp}$.

${ }^{76}$ Como se sabe, fue durante el gobierno de Teodosio el Grande cuando se llevó a cabo una tentativa organizada por revalorar la ciudadanía y las virtudes cívicas que traía aparejadas. El panegírico del emperador compuesto por Pacato Drepanio lo demuestra. En tal sentido el 
6. Finalmente los líderes del Imperio abandonaron las responsabilidades políticas que les cabían por ser ciudadanos y optaron por la jerarquía de la Iglesia católica. Con ello el proceso de transformación de la ciudadanía estuvo completo.

7. Como un epílogo, la ciudadanía romana ahora cristiandad católica romana fue conocida por los líderes germanos que la utilizaron para dictar leyes que se aplicaban diferenciadamente a las sippes germánicas y a los romanos.

BiBLIOGRAFÍA

Fuentes primarias

Agustín, San, De Urbis excidio, II, 2.

Agustín, San, La Ciudad de Dios.

Códex Theodosianus.

Claudio Claudiano, De Consulatu Stilichonis.

Herodiano, Historia del imperio romano después de Marco Aurelio.

Hidacio, Chronicon.

Justiniano, Cuerpo del derecho civil romano, Digesto.

Latinio Pacato Drepanio, Panegyricus Latini Pacati Drepani dictus Teodosio.

Menandro el rétor, Dos tratados de retórica epidictica.

Modestino, Digesto.

Monumenta Germaniae Historica, Auctores Antiquissimi, vol. VIII.

Orosio, Paulo, Historiarum adversus paganos.

Rutilio Namaciano, De Reditu Suo.

San Sidonio Apolinar, Carmina y epistulae, 23.

Varios Autores, Historia Augusta.

Marco Juniano Justino, Epitome de las “bistorias filípicas" de Pompeyo Trogo VI, 2, 12.

Obras generales y monografías

ARCE, Javier, Bárbaros y romanos en Hispania (400-507 A.D.) (2005, primera reimpresión de la segunda edición, Madrid, Marcial Pons Historia, 2011).

ARCE, Javier, Esperando a los árabes. Los visigodos en Hispania (507-711) (Madrid, Marcial Pons Historia, 2011).

Butler, Alban, Vidas de los Santos de Butler (1954, traducción castellana de Wilfredo Guinea, S. J., México, Orozco y Berra, 1965), III.

Castellanos, Santiago, En el final de Roma. (ca. 455-480) (Madrid, Marcial Pons Historia, 2013).

CeCCONI, Giovanni Alberto, Governo imperiale e élites dirigenti nell'Italia tardoantica. Problemi di storia politico-amministrativa (270-476 d.C.) (Como, 1994).

Imperio cristiano que había sucedido a la vieja Roma pagana no hacía más que poner en relieve las viejas nociones de la ciudadanía, pero ahora bajo el tamiz de las virtudes de la cristiandad. Esta idea es la que se encuentra en la base de la noción de una Roma como patria común de todos los pueblos. Sería, por lo demás, el sueño de las épocas que sucederían al viejo Imperio; el recuperar la unidad perdida. Ver DAwson, Christopher, cit. (n. 50), p. 95. 
Chaix de Lavarène, Louis Antoine C., Saint Sidoine Apollinaire et son siécle (Clermont-Ferrand, Ferdinand Thibaud Imprimeur Libraire, 1866).

Dalton, O. M. The letters of Sidonius (Oxford, The Clarendon Press, 1915), I-II.

Dawson, Christopher, Historia de la Cultura Cristiana (1950, traducción castellana, México, Fondo de Cultura Económica, 1997), pp. 91-93.

FERRIL, Arther, La caída del Imperio Romano, las causas militares (1986, traducción castellana de Pilar González Bermejo, México, $3^{\circ}$ edición, Editorial Edaf, 1998).

FOURNIER, Eric, Victor of Vita and the Vandal "persecution": Interpreting Exile in Late Antiquity (Santa Bárbara, University of California, 2008).

Fustel de Coulanges, Numa Dionisio, La ciudad antigua (traducción castellana de Alberto Fano, Madrid, Edaf, 1986).

García Moreno, Luis A., La Antigüedad clásica, el Imperio Romano (Pamplona, Eunsa, 1989), II.

GaRnsey, Peter, Roman Citizenship and Roman law in the Later Empire, en SwaIn, Simon y EDWARDS, Mark (eds.), Approaching Late Antiquity: The transformation from Early to Later Empire (Oxford, Oxford University Press, 2004), pp. 133-155.

Grant, Michel, El mundo romano (1960, traducción castellana de Luis Gil, Madrid, Ediciones Guadarrama, 1960).

Gregoire, J. F. y Collombet F. L., Oeuvres de C. Sollius Apollinaris Sidonius, Traduites en Francais avec le Texte en Regard et des Notes (París, Broché, 1836) I y II.

GuZMÁn Brito, Alejandro, Derecho privado romano (Santiago, Editorial Jurídica de Chile, 1996), I.

Harries, Jill, Imperial Rome AD 284 to 363: The New Empire (Edinburgh, Edinburgh University Press, 2012).

Heather, Peter, La caída del Imperio Romano (2005, traducción castellana de Tomás Fernández Aúz y Beatriz Eguibar, Barcelona, $2^{\circ}$ edición, Editorial Crítica, 2008). Jones, Terry y EReIRA, Alan, Roma y los bárbaros, una historia alternativa (2006, traducción castellana de Tomás Fernández Aúz y Beatriz Eguibar, Barcelona, Editorial Crítica, 2008).

KING, Noel Quinton, The Emperor Theodosius and the Establishment of Christianity (London, Westminster Press, 1961).

LeE, A. D., Information and Frontiers: Roman Foreign Relations in Late Antiquity (Cambridge, Cambridge University Press, 1993).

Le Gall, Joel - Le Glay, Marcel, El Imperio Romano (Madrid, Akal 1995).

Liebeschuetz, Wolf, Citizen Status and Law in the Roman Empire and the Visigothic Kingdom en Pohl, Walter y Reimitz, Helmut (eds.), Strategies of Distinction: The construction of Ethnic Communities, 300-800 (Leiden, Brill editors, 1998), pp. 131-152.

Mangas, Julio, Historia Universal. Edad Antigua, Roma (Barcelona, Vicens Vives, 1999).

MeIKsins Wood, Ellen, De ciudadanos a señores feudales, historia social del pensamiento político desde la Antigüedad a la Edad Media (1ª edición, traducción castellana de Ferran Meler Ortí, Madrid, Paidós, 2011).

Piganiol, André, Historia de Roma (1939, traducción castellana de Ricardo Anaya, Buenos Aires, Eudeba, 1981).

Rosen, William, El fin del Imperio Romano, la primera gran peste de la era global (2007, traducción castellana de Marita Osés, Barcelona, Paidós, 2008). 
Rostovtzeff, Mijail, Historia Social y Económica del Imperio Romano (traducción castellana de Luis López-Ballesteros, Espasa-Calpe S.A., Madrid, 1998), I.

Loyen, André (editor), Sidoine Apollinaire, Poémes (París, Les Belles Lettres, 1960), I, pp. 475-476.

Stevens, C. E., Sidonius Apollinaris and his Age (Oxford, Clarendon Press, 1933).

SHERWIN White, Adrian Nicholas, The roman citizenship (2a edición, Oxford, The Clarendon Press, 2001).

Víctor of Vita, History of the Vandal Persecution (traducción inglesa de John Moorhead, Liverpool, Liverpool University Press, 1992).

Artículos de revistas especializadas

ANDRADEs Rivas, Eduardo, El significado histórico-jurídico de las leyes teodoricianas, en Revista de Estudios Histórico Jurídicos, 38 (Valparaíso, 2016), pp. 47-75.

-- La ciudadania romana bajo los Julio-Claudios en Revista de Estudios Histórico Jurídicos, 29 (Valparaíso, 2007), pp. 165-208.

-- La ciudadanía romana bajo los Flavios y Antoninos en Revista de Estudios Histórico Jurídicos, 30 (Valparaíso, 2008), pp. 47-80.

-- La ciudadanía romana bajo los Severos en Revista de Estudios Histórico Jurídicos, 31 (Valparaíso, 2009), pp. 87-123.

Andrés SANTOS, Francisco Javier, Ciudadanía romana y cosmopolitismo moderno, en Hispania Antiqua, 31 (Valladolid, 2007), pp. 253-265.

BANCALARI, Alejandro, Coexistencia o enfrentamiento entre el derecho romano y los derechos locales de las provincias, en Revista de Estudios Histórico Jurídicos, 26 (Valparaíso, 2004), pp. 25-39.

-- La Constitutio Antoniniana: aproximaciones significado y características, en Semanas de Estudios Romanos, 9 (Valparaíso, 1998), pp. 57-67.

Benario, Herbert W., The Dediticii of the Constitutio Antoniniana, en Transactions and Proceedings of the American Philological Association, 85 (Baltimore, 1954), pp. 188-196.

Chávez Aguilar, Pamela, De urbis excidio de San Agustín: razón y revelación en la comprensión de un acontecimiento histórico, en Teología y Vida, 52 (Santiago, 2011), pp. 245-252.

D'Ors, Álvaro, La formación del “ius novum” en la época tardo clásica, en Revista de Estudios Histórico Jurídicos, 4 (Valparaíso, 1979), pp. 35-49.

EnjuTo S., Begoña, Julio Constancio, paladín de la aristocracia romana del siglo IV D.C., en Habis, 32 (Sevilla, 2001), pp. 495-503.

Horrach Miralles, Juan Antonio, Sobre el concepto de ciudadania: historia y modelos, en Factótum, 6 (Salamanca, 2009), pp. 1-22.

HubeÑAK, Florencio, El hispano Teodosio y la cristianización del Imperio, en Hispania Sacra, 51 (Madrid, 1999) 103, pp. 5-42.

LaWton Sherman, Charles, The Constitutio Antoniniana in the Light of the Gnwmwn Tou Idiou Logou, en Transactions and Proceedings of the American Philological Association, 59 (Baltimore, 1928), pp. 33-47.

LEVY, Ernst, The vulgarization of Roman Law in the Early Middle Ages en Mediaevalia et Humanistica, 1 (Boulder, 1943), pp. 14-40.

Lomas Salmonte, Francisco Javier, Teodosio, paradigma de príncipe cristiano: consi- 
deraciones de Ambrosio, Rufino de Aquileya y Agustin sobre la imperial persona, en Studia Historica, Historia Antigua, 8 (1990), pp. 149-166.

Lo Nero, Carolina, Christiana dignitas: New Christian criteria for Citizenship in the Later Roman Empire en Medieval Encounters, 7 (Leiden, 2001) 2-3, pp. 146-164.

Mathisen, Ralph W., Peregrini, Barbari, and Cives Romani: Concepts of Citizenship and the Legal Identity of Barbarian in the Later Roman Empire en The American Historical Review, 111 (Nueva York, 2006) 4, pp. 1011-1040.

Pareti de Canesa., María Eugenia, Teodosio ante la aristocracia pagana de Roma (Según el panegírico de Pacato), en Semanas de Estudios Romanos, 12 (Valparaíso, 2004), pp. 213-232.

Pellizzari, Andrea, Roma communis nostra patria est. Costanti e variabili del patriottismo romano nei secoli dellimpero, en Atti della Accademia delle Scienze di Torino. Classe di Scienze Morali, Storiche e Filologiche, 133-134 (Turín, 2000), pp. 3-42.

Ribagorda Serrano, Miguel, La pervivencia religiosa pagana en el siglo V: el ejemplo de Rutilio Namaciano, en Antigüedad y Cristianismo, 14 (Murcia, 1997), pp. 179-187.

Andrés Santos, Francisco J., Ciudadanía romana y cosmopolitismo moderno, en Hispania Antiqua, 31 (Valladolid, 2007), pp. 253-265.

Spagnuolo V., Tullio, Diritti locali e modello romano nel principato, en GonZález F., Julián (ed.), Roma y las provincias, realidad administrativa e ideología imperial (Madrid, 1994).

Tagle Martínez, Hugo, Ius sufragii y ius honorum, en Revista Chilena de Derecho 20 (Santiago, 1993), pp. 345-352.

VAN DAM, Raymond, Hagiography and History: the life of Gregory Thaumaturgus, en Classical Antiquity, 1 (Berkeley, 1982) 2, pp. 272-308.

Fuentes electrónicas

Augustinus HipPONENSIS: http://www.augustinus.it/spagnolo/rovina roma/index2. $\underline{\mathrm{htm}}$.

Biblioteca Digital de Castilla y León:http://bibliotecadigital.jcyl.es/i18n/ catalogo imagenes/grupo.cmd? interno=S\&path $=1006419 \&$ presentacion $=$ pagina\&p osicion= 1 \&registrardownload $=0$ https: $/ /$ archive org $/$ details $/$ saintsidoi neapo00lavagoog.

Episcopologio Asturicense: http://bibliotecadigital.jcyl.es/i18n/catalogo imagenes/ grupo.cmd?path=1006419\&interno=S\&posicion=262\&presentacion=pagina

Idatius Aquaeflaviensis Episcopus-Chronicum en http://www.thelatinlibrary.com/ hydatius chronicon.html

Sidonius Apollinaris: http://www.sidoniusapollinaris.nl

Tertulian.org, en http://www.tertullian.org/fathers/ \#sidonius apollinaris

The Latin Library, disponible en http://www.thelatinlibrary.com/sidonius.html

http://revistas.um.es/ayc/article/view/65321/62941. 